\title{
Anxiety, Depression and Sleep Disorders during Coronavirus Disease: A Systematic Review
}

Hayat Sine ${ }^{1 *}$

${ }^{1}$ Clinical Epidemiology and MedicoSurgical Sciences, Faculty of Medicine and Pharmacy, Mohammed V-Rabat University, MOROCCO

* Corresponding author: sinahayet@gmail.com

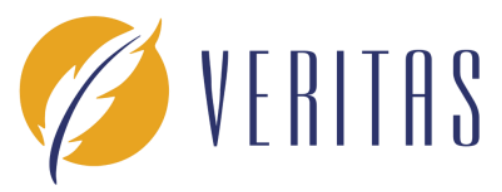

\section{EUROPEAN JOURNAL OF BASIC MEDICAL SCIENCE}

Eur J Basic Med Sci 2020;10(1):11-26

Received: 23 Aug 2020

Accepted: 12 Oct 2020

\begin{abstract}
Background: The world is facing a major health crisis. COVID-19 is a serious disease that has and continues to spread, ravaging lives in every country and causing mental health consequences and sequelae.
\end{abstract}

Methods: A systematic review was conducted by the recommendations of the "Preferred Reporting Elements for Systematic Reviews and Metaanalyses" (PRISMA). The abstract, Scopus, PubMed, and Google scholar databases were specifically reviewed from January 2020 to May 2020.

Results: Twenty-one observational studies with a total of 111407 participants were included in this systematic review. The results suggest a prevalence of symptoms of anxiety, depression, and sleep disorders in response to the COVID-19 pandemic.

Conclusions: COVID-19 is a significant mental health burden. However, it is not possible to generalize the results and there is a need for research in other countries, particularly in developing countries and among vulnerable people.

Keywords: COVID-19, anxiety, depression, sleep disorders, systematic review 


\section{INTRODUCTION}

The world is currently immersed in a tragedy of great magnitude. It began on 30 December 2019, when three bronchoalveolar lavage specimens were collected from a subject with pneumonia of mysterious etiology at Wuhan Jinyintan Hospital. The tests revealed that the virus had specific characteristics of the coronavirus family and was part of the beta coronavirus $2 \mathrm{~B}$ lineage. The COVID-19 virus was then identified and isolated (WHO-China, 2019) ${ }^{1}$.

In its status report of 30 January $^{2}$, WHO reported a total number of 7,818 confirmed cases worldwide, mostly in China, with 82 cases reported in 18 other countries. The virus has spread rapidly in all countries. In hospitals, the number of cases has exceeded all capacity. The WHO has stressed the seriousness of the disease and, on 11 March 2020 deeply alarmed by the rate of transmission and the violence of this disease, WHO has declared COVID-19 a pandemic. This statement triggered a great deal of public unrest, fuelled both by extensive media coverage and initial uncertainty about mortality rates and transmissibility of the virus.

As a result of the preventive actions taken to curb contagion, the COVID-19 pandemic has had consequences in other spheres: changes in family life, closure of educational establishments, societies and common spaces, changes in the rhythms of professional life, isolation, leading to helplessness and feelings of neglect [1]. This pathology has been received by people all over the world as a dangerous health threat, it affects people's lives by affecting their daily attitude and inducing anxiety and depressive reactions [2]. A review of the literature on the correlations between anxiety and mood changes with various infectious diseases that affect adults and children worldwide. This study found significant associations between anxiety and depression and viral diseases such as influenza $A$ (H1N1) and other influenza viruses, varicella and shingles, herpes simplex, HIV/Aids, and hepatitis C [3].

However, a growing body of evidence suggests that psychosocial aspects such as stress and depression may impede the progression of many conditions and increase susceptibility to infectious diseases [4]. A synthesis of human studies on the impact of depression on the immune system and the health implications of these

\footnotetext{
${ }^{1}$ Report of the WHO-China Joint Mission on Coronavirus Disease 2019 (COVID-19)

https: / / www.who.int/docs/default-

source/coronaviruse/who-china-joint-mission-on-covid-19final-report.pdf
}

alterations. The findings revealed that depression can decrease the immune function of cells; as a result, processes such as prolonged infection and delayed wound healing that fuel the sustained production of pro-inflammatory cytokines can be accentuated by depression [5]. For the same purpose, a recent literature review investigated the relationship between immune system alterations and major psychiatric diagnoses such as anxiety and depression. Results showed that psychiatric disorders are correlated with elevated levels of CRP, pro-inflammatory cytokines (IL6, IL-1, and TNFl) and anti-inflammatory factors (TGF, IL-10, SIL-2, IL-1RA), resulting in greater intensity or resistance to treatment of the disease [6].

Infectious diseases and mental health are recognized as major categories of the global burden of disease [7]. Individuals with severe mental illness have higher levels of morbidity and mortality than the general population. They also have higher levels of infectious diseases, noninsulin-dependent diabetes, respiratory diseases, some cancers [8], and HIV infection [4].

Measures taken to contain the COVID-19 pandemic during this health crisis, particularly quarantine, isolation, disruption of social interactions, and a sense of uncertainty about the future, may cause or intensify panic, depression, and anxiety [9]. The heavy casualties of COVID-19 will inevitably have a negative impact on the mental health of the population and a more insidious surge of anxiety, fury, and grief each time the deaths increase [10]. Easily accessible short-term and long-term mental health care services are needed to address this problem [11].

The objective of this study is to systematically evaluate, in the existing literature, the effect of COVID19 on anxiety, depression, and sleep disorders during this pandemic period.

\section{METHODS}

\section{Data Sources and Searches}

This systematic review of the literature was carried out in accordance with the 2009 PRISMA international criteria from the Cochrane Handbook for Systematic Reviews of Interventions [12].

\footnotetext{
${ }^{2}$ Novel Coronavirus(2019-nCoV) Situation Report - 10. https://www.who.int/docs/defaultsource/coronaviruse/situation-reports/20200130-sitrep-10ncov.pdf?sfvrsn=d0b2e480_2
} 
The research was conducted in a database such as Scopus, PubMed, and Google Scholar. Considering the title of the research and to find the studies conducted on, the effect of COVID-19 on anxiety and depression, the keywords such as "COVID-19", "nCoV", "mental health", "psychiatry", "psychology", "anxiety", "depression" and "stress" "traumatic stress ", "sleep disorders ", were used. These keywords were first searched for separately, then in order to improve the quality and enhance the universality of the search, the keywords were combined through search functions and the possible combination was also searched for more community. The search strategy used can be found in Appendix 1. All articles published on "Anxiety, Depression and Sleep disorders during COVID-19" between January 2020- May 2020 were searched. After completing the search for articles, a list of all titles and available abstracts that were mentioned in the data stations was compiled. Relevant searches were classified by type of study. See Table 1 . The language: French or English was imposed on the search and the filtering step.

Table 1. Results of published studies on the change in the level of anxiety, depression and in the quality of sleep during the COVID-19 pandemic

\begin{tabular}{|c|c|c|c|}
\hline $\begin{array}{l}\text { Studies } \\
\text { [21] } \\
\text { China }\end{array}$ & $\begin{array}{l}\text { Design } \\
\text {-This longitudinal study surveyed the } \\
\text { general population twice - during the initial } \\
\text { outbreak, and the epidemic's peak four } \\
\text { weeks later. } \\
\text {-A questionnaire was completed through an } \\
\text { online survey platform ('SurveyStar', } \\
\text { Changsha Ranxing Science and Technology, } \\
\text { Shanghai, China). } \\
\text {-Population: general public living in } \\
\text { mainland China ; } 1738 \text { respondents }\end{array}$ & $\begin{array}{l}\text { Study instrument } \\
\text {-The Depression, Anxiety } \\
\text { Scale measures The } \\
\text { mental health status of } \\
\text { respondents }\end{array}$ & $\begin{array}{l}\text { Results } \\
\text {-Similar non-significant differences were noted between the } \\
\text { two surveys for the DASS-anxiety subscale }[6 \cdot 16(6 \cdot 57) \\
\text { versus } 6 \cdot 15(6 \cdot 94) ; t=0 \cdot 36, p>0 \cdot 05,95 \% \mathrm{Cl}-0 \cdot 58 \text { to } 0 \cdot 60] \text { and } \\
\text { DASS-depression subscale }[6.25(7.16) \text { versus } 6 \cdot 38(7.39) ; t=- \\
0 \cdot 41, p>0 \cdot 05,95 \% \mathrm{Cl}-0 \cdot 77 \text { to } 0 \cdot 50)] \text { mean scores. } \\
\text { - moderate-to-severe anxiety and depression were noted in } \\
8.1 \%, 28.8 \%\end{array}$ \\
\hline $\begin{array}{l}{[29]} \\
\text { Singapore }\end{array}$ & $\begin{array}{l}\text {-the psychological impact of the COVID-19 } \\
\text {-comparison of the prevalence scores } \\
\text { between medical and non medical health } \\
\text { care workers. } \\
\text {-A self-administered questionnaire } \\
\text { population: health care workers : } 470 \\
\text { participants }\end{array}$ & $\begin{array}{l}\text { - Depression, Anxiety, } \\
\text { and Stress Scales (DASS- } \\
\text { 21) }\end{array}$ & $\begin{array}{l}\text {-Sixty-eight }(14.5 \%) \text { participants screened positive for } \\
\text { anxiety, } 42(8.9 \%) \text { for depression, } \\
\text {-The prevalence of anxiety was higher among nonmedical } \\
\text { health care workers than medical personnel }(20.7 \% \text { versus } \\
10.8 \% \text {; adjusted prevalence ratio, } 1.85 \text { [ } 95 \% \mathrm{Cl}, 1.15 \text { to } \\
2.99] ; \mathrm{P}=0.011)\end{array}$ \\
\hline $\begin{array}{l}{[26]} \\
\text { China }\end{array}$ & $\begin{array}{l}\text {-Compare the emotional state, somatic } \\
\text { responses, sleep quality, and behavior of } \\
\text { people in Hubei Province with non-endemic } \\
\text { provinces in China during two weeks during } \\
\text { COVID-19. } \\
\text { - Questionnaires } \\
\text {-Population: people in Hubei Province with } \\
\text { non-endemic provinces in China ( } 939 \\
\text { individuals: students, medical staff, } \\
\text { officials, service personnel, teachers, and } \\
\text { business managers, with the remaining } \\
\text { occupations being freelancers and others. }\end{array}$ & $\begin{array}{l}\text { - The Stress Response } \\
\text { Questionnaire (SRQ) } \\
\text { determined the } \\
\text { emotional state, somatic } \\
\text { responses, and behaviour }\end{array}$ & $\begin{array}{l}\text { - After two weeks, } 10.84 \% \text { of medical staff reported more } \\
\text { stress and anxiety due to increased work pressure. Officials } \\
\text { showed more anxiety ( } 20 \% \text { ) and fear (14\%) when compared } \\
\text { with people with other occupations. } \\
\text { r } 51.52 \% \text { and } 24.24 \% \text { of the study participants in Hubei } \\
\text { Province thought they were possibly or likely to be infected, } \\
\text { respectively. For the non-endemic districts, only } 44.81 \% \text { and } \\
9.05 \% \text { of study participants thought they were possibly or } \\
\text { likely to be infected, respectively }\end{array}$ \\
\hline $\begin{array}{l}{[22]} \\
\text { China }\end{array}$ & $\begin{array}{l}\text {-An observational and cross-sectional } \\
\text { clinical study } \\
\text { - self-reported questionnaires } \\
\text {-population: } 180 \text { participating medical } \\
\text { staff. }\end{array}$ & $\begin{array}{l}\text { - Self-Rating Anxiety } \\
\text { Scale (SAS), } \\
\text {-The Stanford Acute } \\
\text { Stress Reaction (SASR) } \\
\text { questionnaire, } \\
\text {-The Pittsburgh Sleep } \\
\text { Quality Index (PSQI) }\end{array}$ & $\begin{array}{l}\text { - In medical staff, Levels of anxiety were significantly } \\
\text { associated with the levels of stress }(r=0.397, P<0.01) \\
\text { which negatively impacted sleep quality }(r=0.489, P<0.01) \text {. } \\
\text { There was also a significant positive association between } \\
\text { the SASR scores and the PSQI scores }(r=0.457, P<0.01) \text {. }\end{array}$ \\
\hline $\begin{array}{l}{[20]} \\
\text { China }\end{array}$ & $\begin{array}{l}\text { An online survey using snowball sampling } \\
\text { techniques. } \\
\text { Population: the general public ( } 1210 \\
\text { respondents from } 194 \text { cities in China). }\end{array}$ & $\begin{array}{l}\text {-Mental health status } \\
\text { was assessed by the } \\
\text { Depression, Anxiety and } \\
\text { Stress Scale (DASS-21). }\end{array}$ & $\begin{array}{l}\text {-Male gender was significantly associated with higher scores } \\
\text { in DASS anxiety subscale }(\mathrm{B}=0.1995 \% \mathrm{Cl}: 0.05 \text { to } 0.33) \text {, and } \\
\text { DASS depression subscale }(\mathrm{B}=0.12,95 \% \mathrm{Cl}: 0.01 \text { to } 0.23) \text {. } \\
\text {-Student status was significantly associated with higher DASS } \\
\text { anxiety subscale ( } \mathrm{B}=0.16,95 \% \mathrm{Cl}: 0.02 \text { to } 0.30) \text { scores as } \\
\text { compared to those who were employed. } \\
\text { - Specific Up-to-date and accurate health information has } \\
\text { been associated with a lower psychological impact of the } \\
\text { epidemic and lower levels of stress, anxiety and depression } \\
\text { ( } \mathrm{p}<0.05) \text {. } \\
\text { - Female gender, student status, specific physical symptoms } \\
\text { and self-reported poor health were significantly associated } \\
\text { with a greater psychological impact of the epidemic and } \\
\text { higher levels of stress, anxiety and depression }(\mathrm{p}<0.05) \text {. }\end{array}$ \\
\hline
\end{tabular}


Table 1 (continued). Results of published studies on the change in the level of anxiety, depression and in the quality of sleep during the COVID-19 pandemic

\begin{tabular}{|c|c|c|}
\hline Studies & Design & Study instrument \\
\hline [15] & -To assess the mental health burden of & f - GAD-7 (Generalized Anxiety \\
\hline China & $\begin{array}{l}\text { Chinese public during the outbreak, } \\
\text { and to explore the potential influence } \\
\text { factors. } \\
\text { - a web-based cross-sectional survey, } \\
\text { - Population: } 7,236 \text { self-selected } \\
\text { volunteers }\end{array}$ & $\begin{array}{l}\text { Disorder-7) scale } \\
\text { - The Center for Epidemiology } \\
\text { Scale for Depression (CES-D) } \\
\text { - the PSQI (Pittsburgh Sleep } \\
\text { Quality Index) scale }\end{array}$ \\
\hline
\end{tabular}

\section{Results}

-The overall prevalence of GAD, CES-D symptoms, and PSQI were $35.1 \%, 20.1 \%$, and $18.2 \%$, respectively. -There was no statistically significant difference in the prevalence of GAD, depressive symptoms, and sleep quality by gender $(P>0.05$, )

-The prevalence of GAD and depressive symptoms was significantly higher in participants younger than 35 years than in participants aged 35 years or older $(\mathrm{P}<0.001)$.

-Healthcare workers $(23.6 \%)$ reported the highest rate of poor sleep quality $(\mathrm{P}<0.001)$.

[18] Nationwide large- scale survey of -The COVID-19 Peritraumatic China psychological distress in the general Distress Index (CPDI) inquired population of China during the COVID- about the frequency of anxiety, 19 epidemic.

- A self- report questionnaire online -Population: total of 52730 valid depression, specific phobias, cognitive change, avoidance and compulsive behaviour

- Almost 35\% of the respondents experienced psychological distress (29.29\% of the respondents' scores were between 28 and 51 , and $5.14 \%$ of the respondents' scores were $\geq 52$ ).

- Female respondents showed significantly higher psychological distress than their male counterparts (mean $(S D)=24.87$ (15.03) vs 21.41 (15.97), $p<0.001)$. - Individuals between 18 and 30 years of age or above 60 presented the highest CPDI scores (mean $(\mathrm{SD})=27.76$ (15.69) and 27.49 (24.22), - Migrant workers experienced the highest level of distress (mean $(S D)=31.89$ (23.51), $F=1602.501$, $\mathrm{p}<0.001$ ) among all occupations.

- The CPDI score of respondents in the middle region of China (including Hubei) was the highest (mean (SD) 30.94 (19.22), $F=929.306, p<0.001$ )

- After 20 January, negative emotional indicators of

- The Chinese psychoanalytical dictionary simplified LIWC to psychological traits increased in anxiety $(\mathrm{t}(17,747)=$

China on people's mental health,

-Weibo banknotes categories. These lexical characteristics were data sources for word frequency analysis.

-Population: analysis of Weibo banknotes from 17,865 active Weibo users using the online ecological recognition (OER) approach

-Feelings analysis and $\mathrm{t}$-testing of the matched sample was conducted to examine differences in the same group before and after the reporting of COVID-19 on January 20, 2020.
[33] - To assess the anxiety level of Iranian -the anxiety subscale of the Iran general population during COVID-19 outbreak.

- Online questionnaire anxiety of the dass 21 questionnaire which assessed autonomic arousal, skeletal muscle effects, situational anxic the general population of 31 provinces and subjective experience of of Iran anxious impact

-The inferential statistics suggests that the level of anxiety was high among women $(95 \% \mathrm{Cl}[0.1,81.36]$, $\mathrm{p}$ $<0.001$ ), people who more followed corona-related news $(\mathrm{p}<0.001)$ and the age group of $21-40$ years $(\mathrm{p}<$ 0.001 ).

-the level of anxiety was significantly higher among people who had at least one family member, relative, or friend who contracted COVID-19 disease $(95 \% \mathrm{Cl}$ $[1.2,35.03], p<0.001)$.

\begin{tabular}{|c|c|c|c|}
\hline $\begin{array}{l}{[28]} \\
\text { Singapore } \\
\text { and } \\
\text { India }\end{array}$ & $\begin{array}{l}\text { - The association between } \\
\text { psychological outcomes and physical } \\
\text { symptoms among healthcare workers. } \\
\text { - Screening questionnaire } \\
\text {-Population: } 906 \text { Healthcare workers } \\
\text { included doctors, nurses, allied } \\
\text { healthcare workers, administrators, } \\
\text { clerical staff and maintenance } \\
\text { workers. }\end{array}$ & $\begin{array}{l}\text { - Depression Anxiety Stress Scales } \\
\text { (DASS-21) }\end{array}$ & $\begin{array}{l}\text { - The overall mean DASS- } 21 \text { depression subscale score } \\
\text { was } 3.08 \text { (SD } 4.86 \text { ). Of the } 96 \text { healthcare workers who } \\
\text { screened positive for depression, } 50 \% \text { of them were } \\
\text { scored as moderate to very severe depression } \\
\text { - The overall mean DASS- } 21 \text { anxiety subscale score was } \\
3.21 \text { (SD } 4.29 \text { ). Of the } 142 \text { patients who screened } \\
\text { positive for anxiety, } 55.6 \% \text { of them (79) showed } \\
\text { moderate to very severe anxiety } \\
\text { - Those with physical symptoms were more likely to } \\
\text { have a positive screening for depression (OR } 3.23,95 \% \\
\mathrm{Cl} 1.80-5.80, \mathrm{p}<0.001 \text { ), anxiety (OR } 2.66,95 \% \mathrm{Cl} \\
1.69-4.20, \mathrm{p}<0.001) \text {, stress (OR } 3.59,95 \% \mathrm{Cl} 1.51 \text { - } \\
8.56, \mathrm{p}=0.002) \text {, }\end{array}$ \\
\hline
\end{tabular}


Table 1 (continued). Results of published studies on the change in the level of anxiety, depression and in the quality of sleep during the COVID-19 pandemic

\begin{tabular}{|c|c|c|c|}
\hline Studies & & Study instrument & Results \\
\hline $\begin{array}{l}\text { [25] } \\
\text { China }\end{array}$ & $\begin{array}{l}\text { - Psychological status of surgical staff } \\
\text { during the COVID-19 } \\
\text {-population: } 120 \text { subjects from the } \\
\text { surgical medical staff were divided into } \\
\text { two groups ( } 60 \text { in each group) at two time } \\
\text { periods (outbreak period: January } 28 \text {, } \\
2020 \text { to February } 29,2020 \text {; Non-epidemic } \\
\text { outbreak period: March } 2 \text { nd to March } \\
21 \text { st, 2020) }\end{array}$ & $\begin{array}{l}\text { - Anxiety scale, } \\
\text { - The depression screening scale } \\
\text { (PHQ-9) } \\
\text {-Dream anxiety score }\end{array}$ & $\begin{array}{l}\text {-The anxiety score of the surgical staff during the } \\
\text { outbreak period was significantly higher than that } \\
\text { of the surgical staff during the non-outbreak } \\
\text { period }(\mathrm{t}=6.432, \mathrm{P}<0.001) \text {. } \\
\text {-The depression score of surgical staff during the } \\
\text { outbreak period was } 7.333 \pm 2.508 \text {, of which } 24 \\
\text { were positive for depression }(\geq 8 \text { points). The } \\
\text { depression score of surgical staff during the non- } \\
\text { outbreak period was } 4.933 \pm 2.154 \text {, of which } 7 \\
\text { were positive for depression }(\mathrm{t}=4.531 \text {, } \mathrm{P}<0.001) \text {. } \\
\text {-the dream anxiety score the surgical staff during } \\
\text { the outbreak were significantly higher than those } \\
\text { of the surgical staff during the non-outbreak ( } \mathrm{t}= \\
17.365, \mathrm{P}<0.001 \text {; } \mathrm{t}=1.974, \mathrm{P}<0.001) \text {. }\end{array}$ \\
\hline $\begin{array}{l}{[17]} \\
\text { China }\end{array}$ & $\begin{array}{l}\text {-The emotional changes in the elderly } \\
\text { population during the pneumonia } \\
\text { epidemic caused by COVID-19 } \\
\text { - epidemiological survey, using online } \\
\text { questionnaires } \\
\text {-Population: } 1556 \text { elderly people }\end{array}$ & $\begin{array}{l}\text { - The depression screening scale } \\
\text { (PHQ-9) } \\
\text {-The anxiety self-rating scale } \\
\text { (GAD-7). }\end{array}$ & $\begin{array}{l}\text { - } 37.1 \% \text { of the elderly during COVID-19 } \\
\text { experienced depression and anxiety } \\
\text { - Significant difference in anxiety between men } \\
\text { and women }(p<0.05) . M=10.50 \pm 5.15 \text {, } \\
F=11.14 \pm 5.70 \\
\text { - There is a significant difference in the degree of } \\
\text { depression between men and women }(p<0.05) \text {. } \\
M=12.41 \pm 5.11, F=13.05 \pm 5.76 \\
\text { - No significant difference in the level of anxiety } \\
\text { and depression in the different age groups }(p> \\
0.05) \text {. }\end{array}$ \\
\hline $\begin{array}{l}\text { [30] } \\
\text { Italy }\end{array}$ & $\begin{array}{l}\text { - To investigate the psychological distress } \\
\text { perceived by the Italian general } \\
\text { population during the early phase of the } \\
\text { COVID-19 pandemic } \\
\text { - Online survey } \\
\text {-Population: } n=500\end{array}$ & $\begin{array}{l}\text { - Affective temperaments } \\
\text { (depressive, and anxious) were } \\
\text { assessed through the short version } \\
\text { of the validated Italian } \\
\text { Temperament Evaluation of } \\
\text { Memphis, Pisa, Paris and San } \\
\text { Diego-Auto-questionnaire (TEMPS- } \\
\text { A) }\end{array}$ & $\begin{array}{l}\text { - Depression temperaments }(\mathrm{F}=63.98 ; \mathrm{p}<0.001) \text {, } \\
\text { and anxious temperaments }(\mathrm{F}=26.87 ; \mathrm{p}<0.001) \text {. } \\
\text {-Multinomial logistic regression identified anxious } \\
\text { temperament (OR: } 1.39 ; \mathrm{p}=0.008) \text { as a risk factor } \\
\text { for mild psychological distress compared to no } \\
\text { psychological distress, } \\
\text {-Depressive temperaments (OR: } 1.32 ; \mathrm{p}=0.003) \\
\text { were identified as risk factors when comparing } \\
\text { subjects with moderate-to-severe psychological } \\
\text { distress to individuals with only mild distress, }\end{array}$ \\
\hline $\begin{array}{l}{[13]} \\
\text { China }\end{array}$ & $\begin{array}{l}\text { - A cross-sectional observational study } \\
\text { included doctors, nurses, and other } \\
\text { hospital staff throughout Hunan province } \\
\text { between January and March } 2020 \text {. } \\
\text {-Questionnaire } \\
\text {-Population: } n=534 \text { (study included } \\
\text { doctors, nurses, and other hospital staff } \\
\text { throughout Hunan province), }\end{array}$ & $\begin{array}{l}\text { - Questionnaire included } 14 \\
\text { questions that examined the } \\
\text { feelings of the medical staff } \\
\text { during the COVID- } 19 \text { outbreak. } \\
\text { Each question had four choices on } \\
\text { a four point scale ( } 0 \text { =not at all; } \\
1=\text { slightly; } 2=\text { moderately; } 3=\text { very } \\
\text { much). }\end{array}$ & $\begin{array}{l}\text { - Nursing staff felt more nervous and anxious } \\
\text { when on the ward when compared with other } \\
\text { groups }(P=0.02) \text {. }\end{array}$ \\
\hline $\begin{array}{l}{[14]} \\
\text { China }\end{array}$ & $\begin{array}{l}\text { - A cross-sectional study to identify } \\
\text { associations between social media } \\
\text { exposure with mental health problems } \\
\text { - Online survey } \\
\text {-Population: Total of } 4872 \text { participants } \\
\text { from } 31 \text { provinces }\end{array}$ & $\begin{array}{l}\text { - Depression was assessed by The } \\
\text { Chinese version of WHO-Five Well- } \\
\text { Being Index (WHO-5) } \\
\text { - Anxiety was assessed by Chinese } \\
\text { version of generalized anxiety } \\
\text { disorder scale (GAD-7). }\end{array}$ & $\begin{array}{l}\text { - The prevalence of depression, anxiety and } \\
\text { combination of depression and anxiety (CDA) was } \\
48.3 \%(95 \% \mathrm{Cl}: 46.9 \%-49.7 \%), 22.6 \%(95 \% \mathrm{Cl}: 21.4 \%- \\
23.8 \%) \text { and } 19.4 \%(95 \% \mathrm{Cl}: 18.3 \%-20.6 \%) \text { during } \\
\text { COVID-19 outbroke in Wuhan, China. More than } \\
80 \%(95 \% \mathrm{Cl}: 80.9 \% 83.1 \%) \text { of participants reported } \\
\text { frequently exposed to social media } \\
\text { - frequently SME can increase the adjusted odds } \\
\text { (OR = } 1.72 \text {, } 95 \% \mathrm{Cl}: 1.31-2.26) \text { of anxiety } \\
\text { compared with less SME }\end{array}$ \\
\hline $\begin{array}{l}{[27]} \\
\text { China }\end{array}$ & $\begin{array}{l}\text { - Mental health impacts of the COVID-19 } \\
\text { pandemic among people with or without } \\
\text { quarantine managements } \\
\text { - Data gathered with a mobile app called } \\
\text { "Sojump" (www. sojump.com) } \\
\text {-Population: } 1443 \text { participants with } \\
\text { quarantine and } 836 \text { participants without } \\
\text { quarantine }\end{array}$ & -Anxiety Disorder Scale (GAD-7), & $\begin{array}{l}\text { - No significant differences were found for } \\
\text { positive screening for GAD-7 between participants } \\
\text { with and without quarantine (all } p \geq 0.303 \text { ). }\end{array}$ \\
\hline
\end{tabular}


Table 1 (continued). Results of published studies on the change in the level of anxiety, depression and in the quality of sleep during the COVID-19 pandemic

\begin{tabular}{ll}
\hline Studies & Design \\
\hline [19] & - To measure the psychological impact when \\
China & members of the workforce began to return to \\
& work during the peak of the COVID-19 epidemic \\
& when strict infection control was in place. \\
& - An online questionnaire was administered via \\
& an online platform \\
& -Population: 1323 members of the workforce \\
& were invited to participate in the study.
\end{tabular}

\section{Study instrument Results}

-Depression, Anxiety and -after the large scale of quarantine and lockdown,

Stress Scale (DASS-21), $\quad 42.3 \%$ had returned to the workplace for 15 days or more, $27.2 \%$ were still working at home and had not yet returned to workplace despite the approval, and $9.2 \%$ had returned to the workplace for 8 to 14 days.

-About $3.8 \%, 3.7 \%, 1.5 \%$ of respondents reported moderate to severe anxiety, depression, stress respectively.

-There were no significant differences between workers/technical staff and managers/executives in the mean score and severity of, depression, anxiety, stress an ( $p$ > 0.05).

\begin{tabular}{lll}
\hline [31] & - to identify mental health characteristics of & - Generalized anxiety (GAD- \\
Usa & adults with dysfunctional coronavirus anxiety & 7 ) \\
& - online survey & - Depression (PHQ) \\
& -Population: 1237 MTurk workers & - The Coronavirus Anxiety \\
& & Scale (CAS)
\end{tabular}

-The rates of coronavirus infection, dysfunctional coronavirus anxiety, generalized anxiety, and depression were $4.9 \%, 25.4 \%, 36.0 \%, 40.3 \%$, respectively.

- Anxiety was associated with coronavirus infection (odds ratio (OR) $3.04,95 \% \mathrm{Cl} 1.28-7.25$ ), generalized anxiety (OR $1.13,95 \% \mathrm{Cl} 1.06-1.20)$, depression (OR 1.09, 95\% Cl 1.03-1.15), perceived lack of social support (OR1.16,95\%Cl1.04-1.28), and suicidal ideation(OR $1.24,95 \% \mathrm{Cl} 1.13-1.37$ ).

[32] - To measure the level of psychological well-
Denmark being in Denmark during the COVID-19
pandemic and to compare it to prior Danish
data obtained with the same measure.
-Population: 2458 respondents.

\section{- the WHO-5 well-being} scale - The survey also contained six questions regarding the experienced level of anxiety/depression over the past 2 weeks reported on a scale from 0 (not present) to 10 (present to an extreme degree).

- The proportion of respondents from the CCDPS 2020 with WHO- 5 scores $<50$ was significantly higher than for the DMHWBS 2016 survey for the total sample $(25.4 \%$ vs. $22.5 \%, p<0.001)$ and for females ( $28.8 \%$ vs. $24.6 \%, p=0.005)$, but not for males $(21.8 \%$ vs. $20.0 \%, p=0.110$ ).

-strong negative correlations between the reported levels of depression/anxiety and the WHO-5 scores

-The results of this study suggest that the psychological well-being of the general Danish population is affected negatively by the COVID-19 pandemic - and more so for females than for males.

\begin{tabular}{|c|c|c|}
\hline $\begin{array}{l}{[23]} \\
\text { China }\end{array}$ & $\begin{array}{l}\text { - investigate the effects of social capital on } \\
\text { sleep quality and the mechanisms involved in } \\
\text { people who self-isolated at home for } 14 \text { days in } \\
\text { January } 2020 \text { during the COVID-19 epidemic in } \\
\text { central China. } \\
\text { - Cross-sectional study design } \\
\text { - Population: Individuals ( } n=170 \text { ) who self- } \\
\text { isolated at home for } 14 \text { days in central China, } \\
\text { completed self-reported questionnaires on the } \\
\text { third day of isolation. }\end{array}$ & $\begin{array}{l}\text {-Anxiety was assessed using } \\
\text { the Self-Rating Anxiety } \\
\text { Scale (SAS) questionnaire, } \\
\text { - The Pittsburgh Sleep } \\
\text { Quality Index (PSQI) } \\
\text { questionnaire. } \\
\text { - social capital using the } \\
\text { PSCI-16 questionnaire } \\
\text { - The SASR questionnaire } \\
\text { used to measure stress }\end{array}$ \\
\hline $\begin{array}{l}{[24]} \\
\text { China }\end{array}$ & $\begin{array}{l}\text { - Investigated depressive and anxiety symptoms } \\
\text { among students in Hubei province, China, } \\
\text { - Servy investigation through an online } \\
\text { crowdsourcing platform } \\
\text { (https://www.wjx.cn/). } \\
\text {-Population: A total of } 2330 \text { students in grades } 2 \\
\text { through } 6 \text { in } 2 \text { primary schools in Hubei } \\
\text { province, of whom } 845 \text { were from Wuhan and } \\
1485 \text { were from Huangshi, }\end{array}$ & $\begin{array}{l}\text { - Depressive and anxiety } \\
\text { symptoms measured by the } \\
\text { Children's Depression } \\
\text { Inventory-Short Form (CDI- } \\
\text { S). }\end{array}$ \\
\hline
\end{tabular}

- The PSCl-16 score of the study participants was positively associated with the SAS score $(b=0.619$, $\mathrm{P}<0.001)$ and the SASR score $(\mathrm{b}=0.327, \mathrm{P}<0.001)$. . Correlation analysis showed positively associated with the SAS score $(r=0.619, P<0.01$ and the PSQI score $(r=0.479, P<0.01)$.

\section{- The SAS score of the study participants} significantly affected the SASR score $(b=0.351$, $P<0.001)$ and the PSQI score $(b=0.253, P<0.001)$. - A total of 403 students (22.6\%) and 337 students $(18.9 \%)$ reported depressive and anxiety symptoms, respectively.

Students in Wuhan had significantly higher CDI-S scores than those in Huangshi $(B, 0.092[95 \% \mathrm{Cl}$, $0.014-0.170]$ ), with a greater risk of depressive symptoms (odds ratio, 1.426 [95\% Cl, 1.138-1.786]). - There was no significant association between demographic characteristics and anxiety symptoms $(\mathrm{PTSD})=$ Post-traumatic stress disorder, $(P)=$ Prevalue, $(\mathrm{Cl})=\mathrm{A}$ confidence interval, $\mathrm{R}=$ Correlation coefficient, $\mathrm{B}=$ Regression coefficient, $\mathrm{SD}=$ standard deviation, OR=An odds ratio , DMHWBS 2016= The Danish Mental Health and Well-Being Survey 2016

\section{Study selection}

Of all the articles related to the subject of the journal, only Cross-sectional observational studies that evaluate anxiety and depression or sleep disorders problems encountered by the general population (health care workers, students, civil servants, personal services, teachers, business leaders, nurses, seniors, etc.) during COVID-19 are included. 


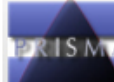

PRISMA 2009 Flow Diagram
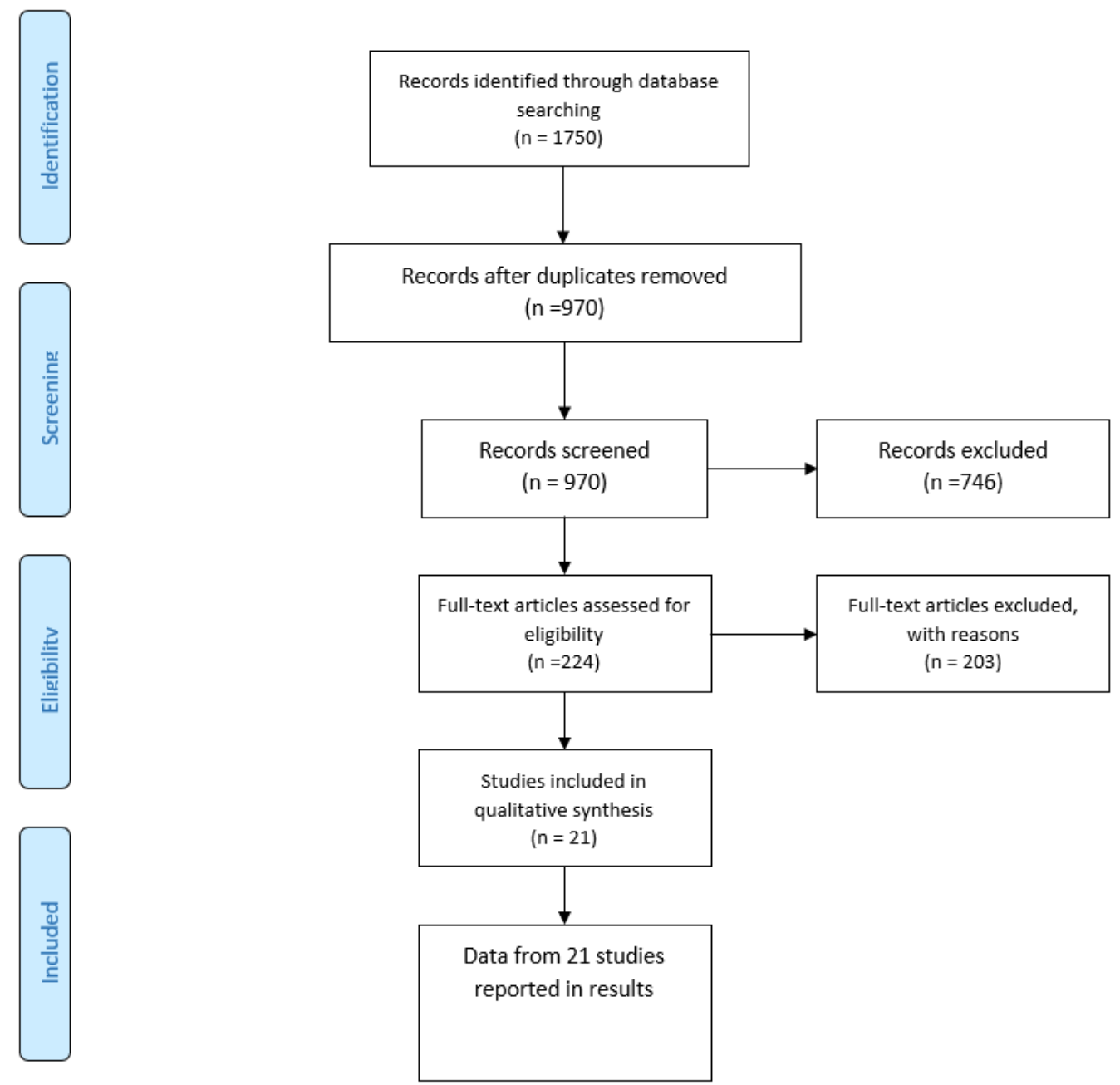

Figure 1. Flowchart of the results of the literature search From: Moher D, Liberati A, Tetzlaff J, Altman DG, The PRISMA Group (2009). Preferred Reporting Items for Systematic Reviews and MetaAnalyses: The PRISMA Statement. PLoS Med 6(7): e1000097. doi:10.1371/journal.pmed1000097

Articles that are published in the form of a letter to the editors/comments, point of view, or that report inappropriate information were excluded.

The selection, according to the inclusion and exclusion criteria defined in advance, was carried out independently, for each step of reading titles, summaries, and complete texts.

A meta-analysis was neither planned nor conducted.

\section{RESULTS AND DISCUSSION}

In the initial search, 1750 articles were found in different databases. All papers were screened by reading their abstracts and 780 of them were eliminated due to being duplicates found in different databases. After evaluating the full texts, 740 studies were excluded due to presenting data that were irrelevant to our aim.

224 full-text articles were evaluated for eligibility. The selection process for these studies is illustrated in Figure 1 using the PRISMA flow diagram (http: / / www.prisma-statement.org/).

224 full-text articles were assessed for eligibility. After a full survey 203 articles had to be excluded due to methodological limitations: 9 were systematic reviews, 
30 were letters to the editor, 50 were mental health and COVID comments, 76 studies did not address the same variables sought and 38 were ideas/viewpoints.

The twenty-one observational studies with a total of 111407 participants were included in this systematic review.

The characteristics of the included studies are presented in Table 1. The twenty-one observational studies with a total of 111407 participants included in this systematic review were conducted in: China [1327], Singapore [28,29], India [28], Italy [30], USA [31], Denmark [32] and Iran [33].

According to the results, participants in the observational studies included in this systematic review can be classified into six broad categories: General population $[15,18,20,21,30,32,33]$, health professionals $[13,23,25,26,28]$, Child students [24], the elderly [17], isolated people in their forties [19,22,27], and users exposed to social networks and web platform $[14,16,31]$.

\section{Outcomes Measures}

In the majority of the studies reviewed, more than one measure was used to assess anxiety and depression. using an Depression, Anxiety Scale [19-21,28,29,33], Self-Rating Anxiety Scale (SAS) [22,23,25], Anxiety Disorder Scale (GAD-7) [14,15,17,27,31], The Stress Response Questionnaire (SRQ) determined the emotional state [26], The COVID-19 Peritraumatic Distress Index (CPDI) inquired about the frequency of anxiety, depression [18], The Chinese psychoanalytical dictionary simplified LIWC [16], Affective temperaments (depressive, and anxious) -Autoquestionnaire (TEMPS-A) [30], The Coronavirus Anxiety Scale (CAS) [31], the Children's Depression InventoryShort Form (CDI-S) [24], The Center for Epidemiology Scale for Depression (CES-D) [15], The depression screening scale (PHQ-9) [17,24,31], and The WHO-Five Well-Being Index (WHO-5) [14,32].

Sleep quality was assessed in Three studies and measured with the Pittsburgh Sleep Quality Index (PSQI) questionnaire $[15,22,23]$.

\section{Outcomes Measures}

In the majority of the studies reviewed, more than one measure was used to assess anxiety and depression. using an Depression, Anxiety Scale [19-21,28,29,33], Self-Rating Anxiety Scale (SAS) [22,23,25], Anxiety
Disorder Scale (GAD-7) [14,15,17,27,31], The Stress Response Questionnaire (SRQ) determined the emotional state [26], The COVID-19 Peritraumatic Distress Index (CPDI) inquired about the frequency of anxiety, depression [18], The Chinese psychoanalytical dictionary simplified LIWC [16], Affective temperaments (depressive, and anxious) -Autoquestionnaire (TEMPS-A) [30], The Coronavirus Anxiety Scale (CAS) [31], the Children's Depression InventoryShort Form (CDI-S) [24], The Center for Epidemiology Scale for Depression (CES-D) [15], The depression screening scale (PHQ-9) $[17,24,31]$, and The WHO-Five Well-Being Index (WHO-5) [14,32].

Sleep quality was assessed in Three studies and measured with the Pittsburgh Sleep Quality Index (PSQI) questionnaire [15,22,23].

\section{Anxiety and Depression Disorders in the General Population during COVID-19}

Seven papers evaluated the influence of COVID-19 on anxiety, depression, and sleep quality in the general population. According to [21], moderate to severe anxiety and depression symptoms were noted in $8.1 \%$, $28.8 \%$ of mainland residents in China (median age $=35.6$ years) during the initial outbreak, and the epidemic's peak four weeks later.

The same results are confirmed by [15] who showed that the overall prevalence of DAG, CES-D and PSQI symptoms was $35.1 \%, 20.1 \%$, and $18.2 \%$ respectively in the Chinese population (median age $=35.3 \pm 5.6$ years) with no significant gender difference $(P>0.05)$.

The prevalence of symptoms of GAD and depression was significantly higher in youth under 35 years of age than in participants 35 years of age or older $(P<0.001)$. indeed, the study conducted on the general population of 194 cities in China (median age 35. 4 years) found that youth were significantly associated with higher scores on the DASS anxiety subscale $(\mathrm{B}=0.16,95 \% \mathrm{Cl}$ : 0.02 to 0.30 ), while female sex, specific physical symptoms, and self-reported poor health were significantly associated with a greater psychological impact of the epidemic and higher levels of stress, anxiety, and depression ( $p$ 0.05) [20].

[18] also made key findings: women showed significantly higher psychological distress than their male counterparts (mean $(S D)=24.87(15.03)$ versus 21.41 (15.97), $p<0.001$ ), and Individuals aged 18 to 30 or over 60 years had the highest CPDI scores (mean (SD) 
$=27.76$ (15.69) and 27.49 (24.22), especially those living in central China (mean (SD) 30.94 (19.22), $F=$ 929.306, $\mathrm{p}<0.001$ ).

Apparent results were found in the Iranian population, as a study conducted in 31 provinces of Iran found high levels of anxiety in women $(95 \% \mathrm{Cl}[0.1,81.36], \mathrm{p}<$ $0.001)$, and in the $21-40$ age group $(p<0.001)$ [33].

In Italy, anxious ( $\mathrm{F}=26.87 ; \mathrm{p}<0.001)$ and depressed $(F=63.98 ; p<0.001)$ temperaments were more common. in the Italian population (median age $=44$ years); these temperaments were also presumed to be aggravating factors when we compare subjects presenting moderate to severe psychological distress with individuals presenting only mild (OR: $1.39 ; \mathrm{p}=$ 0.008 ) and depressive (OR: 1.32; $p=0.003$ ) distress [30].

In Denmark [32] compared - in a population of 2458 participants (mean age $=49.1$ years) the psychological well-being score during COVID-19 with the results of the DMHWBS score from a survey conducted in 2016; the results showed that the psychological well-being of the Danish population, in general, is negatively affected by the COVID-19 pandemic - and even more so for women than for men. The results show that the psychological well-being of women $(28.8 \%$ vs. $24.6 \%, p=0.005)$ but not men $(21.8 \%$ vs. $20.0 \%, p=0.110)$ with strong negative correlations between reported levels of depression/anxiety and WHO-5 scores.

\section{Anxiety and Depression Disorders in the Health Workers during COVID-19}

In total six studies are interested in the disorders of anxiety, depression, and quality of sleep of medical personnel caused by COVID-19. Most observational research has been done in China, the country of the spread of the virus. According to the results of [23], among medical staff anxiety levels were significantly associated with stress levels $(r=0.397, P<0.01)$, which had a negative impact on the quality of sleep $(r=0.489$, $P<0.01)$. There was also a significant positive association between the SASR scores and the PSQI scores $(r=0.457, P<0.01)$. Similar results were observed among medical staff in Hubei province, of which $10.84 \%$ of medical staff reported increased stress and anxiety due to increased work pressure [26]. The surgical staff was not spared from the psychological disorders caused by the COVID-19 pandemic, the study from [25] showed that The anxiety, depression, and Dream anxiety score during the hatching period was significantly higher than that of the surgical staff during the non-hatching period $(\mathrm{t}=6.432, \mathrm{P}<0.001, \mathrm{t}=4.531$, $P<0.001$ and $t=1.74, P<0.001$ respectively) also The nursing staff felt more nervous and anxious in the service compared to the other groups [13].

The same results were advanced by a study done in Singapore and India [28], which revealed that $50 \%$ of healthcare workers obtained a score of moderate to very severe depression and anxiety, with a significant correlation of physical symptoms with depression (OR $3.23,95 \% \mathrm{Cl} 1.80-5.80, \mathrm{p}<0.001$ ), anxiety (OR 2.66, 95\% $\mathrm{Cl} 1.69-4.20, \mathrm{p}<0.001)$ and stress (OR $3.59,95 \% \mathrm{Cl} 1.51$ 8.56, $p=0.002$ ). However, the prevalence of anxiety was higher among non-medical health workers than among medical staff (20.7\% versus $10.8 \%$; adjusted prevalence ratio, $1.85[95 \% \mathrm{Cl}, 1.15$ at 2.99$] ; \mathrm{P}=0.011$ ) [29].

\section{Anxiety and Depression Disorders in the Isolated and Quarantine Population during COVID-19}

Three studies included in this systematic review treated quarantine and isolation during COVID-19 [22], studied the effect of isolation during 14 days during COVID-19 on anxiety and quality of sleep in 170 individuals from central china, the results indicated Anxiety levels correlated with stress levels $(b=0.351, P<0.001)$, which reduced sleep quality $(b=0.253, P<0.001)$, and that levels of social capital may affect mental health and sleep ( $\mathrm{PSCl}-16$ score was positively associated with the SAS score $(b=0.619, P<0.001)$ and the SASR score $(b=0.327, P<0.001)$. but there were no significant differences for positive GAD-7 screening between participants with and without quarantine (all $p \geq 0.303$ ) [27]. However $3.8 \%, 3.7 \%, 1.5 \%$ of people returning to work after isolation during the peak of the COVID-19 epidemic reported moderate to severe anxiety, depression, stress, with high correlation with anxiety and sleep quality: SAS score $(r=0.619, P<0.01$ and the PSQI score $(r=0.479, P<0.01)$ [19].

\section{Anxiety and Depression Disorders in the Child Student during COVID-19}

[24] have studied the prevalence of anxiety and depression symptoms out of 2330 students in grades 2 through 6 in 2 primary schools in Hubei province, of whom 845 were from Wuhan and 1485 were from Huangshi. A total of 403 students $(22.6 \%)$ and 337 students $(18.9 \%)$ reported depressive and anxiety symptoms, respectively. 
Students in Wuhan had significantly higher CDI-S scores than those in Huangshi $(B, 0.092$ [ $95 \% \mathrm{Cl}, 0.014-0.170])$, with a greater risk of depressive symptoms (odds ratio, $1.426[95 \% \mathrm{Cl}, 1.138-1.786])$.

\section{Anxiety and Depression Disorders in the Elderly Population during COVID-19}

On 1556 of elderly people (middle age $=67.3$ years), $37.1 \%$ during COVID-19 suffered from depression and anxiety, with a prevalence of anxiety and depression in women compared to men $(\mathrm{p}<0.05 . M=10.50 \pm 5.15, F$ $=11.14 \pm 5.70$ and $(p<0.05) \cdot M=12.41 \pm 5.11, F=13.05$ \pm 5.76 respectively) according to the study of [17].

\section{Anxiety and Depression Disorders in Users Exposed to Social Networks and Web Platforms during COVID-19}

Study in China analyzed emotional indicators of psychological traits of 17,865 active Weibo users (middle age 33.2 years) in a same group before and after the declaration of COVID-19 on January 20, 2020. According to the results after January 20, negative emotional indicators of psychological traits increased in anxiety $(\mathrm{t}(17,747)=-35.962, \mathrm{p}<0.001)$, depression $(\mathrm{t}$ $(17,747)=-10,717, p<0.001)$ and outrage $(t(17,747)=$ 5.500, $\mathrm{p}<0.001)$ [16].

Indeed a study has sought associations between exposure to social media and mental health problems during the COVID-19 crisis in Wuhan, China. According to the conclusions More than $80 \%$ (95\% Cl: $80.9 \% 83.1 \%$ ) of the participants declared to be frequently exposed to social media, in parallel, the prevalence of depression, anxiety and the combination of depression and anxiety ( $A D C)$ was $48.3 \%$ (95\% Cl: $46.9 \%-49.7 \%), 22$, $6 \%(95 \% \mathrm{Cl}: 21.4 \%-23.8 \%)$ and $19.4 \%(95 \% \mathrm{Cl}: 18.3 \%-$ $20.6 \%)[14]$.

Along the same lines [31], revealed a high rate of general anxiety and depression (36.0\%, 40.3\% respectively) among MTurk workers. In addition, anxiety in this group of people was associated with coronavirus infection (odds ratio $(\mathrm{OR}) 3.04,95 \% \mathrm{Cl} 1.28$ 7.25), generalized anxiety (OR $1.13, \mathrm{Cl} 95 \%$ 1.06-1.20), depression (OR 1.09, 95\% Cl 1.03-1.15)), perceived lack of social support (OR $1.16 .95 \% \mathrm{Cl} 1.04-1.28)$ and suicidal thoughts (OR 1.24, $95 \% \mathrm{Cl} 1.13-1.37)$.

\section{Factors Associated with Levels or Changes in Anxiety and Depression Symptoms during COVID-19}

According to some studies included in this systematic review, physical symptoms, poor self-rated health, and a history of chronic disease were significantly associated with anxiety or depression $p<0.05[21,28]$. Indeed, according to the study carried out by poor selfrated health was significantly associated with a greater psychological impact of the epidemic $(\mathrm{B}=0.76,95 \% \mathrm{Cl}$ : 0.02 to 1.49 ) and an under -higher DASS stress scale ( $B$ $=0.45,95 \% \mathrm{Cl}: 0.02$ to 0.88$)$, DASS anxiety subscale $(\mathrm{B}$ $=0.90,95 \% \mathrm{Cl}: 0.22$ at 1.58$)$ and DASS depression subscale $(B=0.65,95 \% \mathrm{Cl}: 0.10$ to 1.20$)$ compared to those whose self-rated health status is very good or good [20]. Levels of psychological distress can also be exacerbated by the fear of being a carrier of the virus [28]. Admittedly, the level of anxiety was significantly higher in people who had at least one family member, relative or friend suffering from COVID-19 disease $(95 \%$ $\mathrm{Cl}[1,2,35,03], \mathrm{p}<0.001$ ) [33]. Also, dysfunctional coronavirus anxiety was associated with coronavirus infection (odds ratio (OR) 3.04, 95\% Cl 1.28-7.25) [31].

However, exposure to the media and spending hours searching for information on the Internet can be a risk factor. Indeed, the most common source of health information on COVID-19 came from the Internet $(93.5 \%)$ [20].

In Iran, more than $94 \%$ of people always / sometimes follow COVID-19 news [33], and around a third (31.4\%) of people spend more than 2 hours a day watching the news about COVID-19 in the media [21]. despite the fact that the majority of respondents $(75.1 \%)$ were very satisfied or somewhat satisfied with the amount of health information available but the more people followed the news of coronaviruses, the more the level and severity of their anxiety symptoms increased ( $p$ $<0.001)$ [33], and people who spent too much time thinking about epidemics ( $\geq 3$ hours) were more likely to develop symptoms of anxiety(Huang and Zhao, 2020). $82.0 \%$ of participants who were frequently exposed to social media had high levels of anxiety and a combination of depression and anxiety [14].

The studies included in this systematic review have highlighted several factors that can, in particular, accentuate anxiety, depression, and sleep disorders in health workers. The main factors associated with stress were concerns for personal safety $(P<0.001)$, concerns 
for their families $(P<0.001)$, and concerns for patient mortality $(P=0.001)$. Medical staff aged 31 to 40 were more concerned about their family's infection than the other groups $(2.46 \pm 0.72)$. The lack of protective clothing $(P=0.0195)$ and exhaustion due to the increase in working hours $(P=0.03)$ also increased significantly among seniors. The safety of their colleagues and the lack of treatment for COVID-19 were considered to be important factors inducing psychological disorders in all medical personnel, with no significant differences between the study groups [13]. Also, The fear of transmitting the disease to their own families is particularly high due to reports of asymptomatic transmission of COVID-19 [28]. Surgeons and anesthesiologists, who must also perform intubation and other operations, have experienced a high risk of enormous psychological pressure that has caused anxiety and depression [25].

Most studies have found that women have reported higher levels of anxiety and depression than men $[15,18,20,21,30,31,33]$.

the same conclusion was made for young students whose level of anxiety and depression increased $[20,24,26]$, the uncertainty and the potential negative impact on academic progress could have a negative effect on the mental health of students according to [20].

in the elderly, certain psychological changes that occur as their bodily functions decrease: for example memory impairment, intellectual changes, emotional changes, psychological loneliness, and fear, feeling of inferiority, doubt can also aggravate their anxiety, depression or their sleep disorders [17].

Isolation and quarantine are also among the factors described as increasing symptoms of anxiety, depression, and sleep disturbances in some of the studies cited in this review. Indeed, people who isolate themselves at home will experience physical stress due to lack of space for physical activity, stress due to limited social interactions and anxiety associated with fear of the consequences of infection [22]. However, some strict measures taken by the government, for example in Wuhan according to [14] could lead to more serious mental health problems among local populations. Also according to a study carried out in Italy, people with anxious or depressed temperaments are more likely to perceive the epidemic of COVID-19, and the associated containment measures, as a painful and negative effect accumulated in response to social isolation [30]. But it is essential to become aware of the range of factors associated with PTSD, stress, anxiety, depression, and insomnia among people who return to work after quarantine and lockout during the COVID pandemic- 19 and even after [19].

One study cited political problems as risk factors. according to [33] the anxiety, depression, and sleep quality disorders observed in the population of his study are due to the inability of the Iranian government to provide health services to the population following sanctions severe and the " maximum pressure " practiced by the USA.

\section{Adaptation Strategies and Measures}

Several articles have addressed the use of specific strategies to provide mental health care to people affected by the COVID-19 epidemic [13,15-20,22,25$31,33]$.

For medical personnel, the availability of strict infection control guidelines, specialized equipment, recognition of their efforts by hospital management and government, and the reduction of reported cases of COVID-19 has brought psychological benefit [13]. Also, the social support of medical personnel had an indirect effect on several paths or stages. Indeed Levels of social support for medical staff were significantly associated with self-efficacy and quality of sleep and negatively associated with a degree of anxiety and stress [22]. However, health workers also need psychological intervention [25]., this psychological support could include counseling services and the development of support systems between colleagues [29]. Also, in family settings, psychoeducation and psychological interventions online, on smartphones or platforms could also provide a network of support for people in epidemic situations, to fight against depression in [20]. these psychological interventions should be directed to vulnerable populations [15]. Indeed, more attention must be paid to young people, women, and the elderly $[18,20]$, that more humane care and psychological intervention measures should be granted to them [17].

Given the peculiarity of self-isolation [27], the various psychosocial therapies were required such as telephone assistance and relevant online advice [16], Online forums or hotlines for advice and information sharing during the COVID-19 pandemic [19,31]. Encouraging communication with relatives and friends via the Internet or by telephone [22]. 
Coping strategies also include the role of the media, which disseminates the number of people recovering from COVID-19 infection on a daily basis, and evidencebased scientific and medical information has been provided to raise awareness, which could alleviate some of the fear caused by this new infectious disease, and reduce anxiety levels [26]. Admittedly, about $96.9 \%$ of people preferred regular updates for the latest information and this was found to be significantly associated with scores below the DASS anxiety subscale $(B=-0,62,95 \% \mathrm{Cl}:-1.00$ to -0.24$)$ according to the study by [20]. Maintaining a normal work and rest rhythm, exercising regularly, and not paying attention to information about the epidemic before falling asleep can also be measured to promote the quality of sleep [15]. In this regard, mental health professionals are advised to educate the public about common psychological consequences, promote healthy behaviors, advise people to reduce their exposure to negative information, and prevent social isolation by using alternative means of communication such as virtual networks [33].

However, after the COVID-19 pandemic, increased demand for psychiatric care will be detected [32]. Then care and support strategies will be necessary to improve the social capital and the state of mental health of people isolated during epidemics of infectious diseases [22]. Every effort should be made to provide psychological support and interventions once an acute infection has been ruled out [28]. Interventions to promote mental health among the general population should be implemented quickly, taking into account individual backgrounds and characteristics [30]. According to [18] to deal with the situation after COVID19 , accessibility to medical resources and the public health system should be further strengthened and improved, especially after examining the initial management and management of COVID-19 national strategic planning and coordination of psychological first aid during major disasters, potentially dispensed by telemedicine, should be put in place and a complete crisis prevention and response system including epidemiological surveillance, screening, orientation, and targeted intervention should be implemented to reduce psychological distress and prevent new mental health problems.

\section{DISCUSSION}

The studies cited in this systematic review identified a considerable number of psychological problems affecting the general population during COVID-19.
Overall, the results showed that 21/21 studies [13-33] have reported a prevalence of anxiety, depression and poor sleep quality in the general population as a result of the atypical infectious pneumonia that has ravaged the world. In fact, according to several studies, the relationship between infectious disease and anxiety, depression, or sleep disorders has been well established [34-37].

Healthcare workers are exposed to very high levels of anxiety, depression, and sleep disturbance as a result of the COVID-19 pandemic, due to exhaustion from increased work hours, fear of transmitting the disease to their own families, concerns about patient mortality, and lack of protective clothing. Other reviews have also shown similar findings that health care professionals are at greater risk of developing psychiatric symptoms [38]. Also, a meta-analysis demonstrated a positive relationship between critical incidents and symptoms of depressive anxiety among health professionals [39].

However, according to this systematic review, women were much more likely than men to develop symptoms of anxiety and depression [15,18,20,21,26,30,31-33]. These findings are similar to those revealed by a systematic review that examined the prevalence of anxiety disorders in the general population, as reported by this study the substantial prevalence of anxiety disorders in general was (3.8-25\%), and particularly among women $(5.2-8.7 \%)$ and young adults $(2.5-9.1 \%)$ [40]. Indeed most women experience greater fear and anxiety than men throughout their lives [41]. In addition, in response to a hostile situation, women are more likely to use emotionally focused management methods, which are less effective in alleviating distress than problem-based management strategies [42].

The social isolation associated with quarantine can also be a trigger for several mental health consequences, including depressive symptoms, anxiety, stress, and sleep disturbances $[19,22,27]$. Similar conclusions were reached by a systematic review that examined the psychological impact of quarantine in ten countries and included people with SARS, Ebola, pandemic H1N1, Middle East Respiratory Syndrome, and equine influenza. Most of the studies reviewed reported negative psychological effects, including the presence of symptoms of post-traumatic stress disorder, confusion, and anger [43]. People in quarantine often fear being infected or infecting others, a concern that may be reinforced by misinformation or incomplete data [43]. In fact, according to the results of this systematic review, people who spend more time in the 
Online social networking sites media and internet searching for COVID-19 information are more likely to have negative emotional indicators of increased psychological traits in anxiety, depression, and insomnia [14,16,31]. In addition, several systematic reviews have synthesized evidence of the influence of social media use on depression, anxiety, and psychological distress [44-46].

However, several strategies have been put in place by the government of China to deal with the psychological damage caused by COVID-19 including counseling services and the development of support systems, psychoeducation and psychological interventions online, on smartphones or platforms to provide a support network for people in epidemic situations, to combat depression, also the development of synchronous telemedicine services for diagnostic and counseling purposes $[13,15,18,20,21,23,26-28]$. Similar recommendations have been proposed in Iran [33], Singapore, and India [28,29].

In Italy, mental health interventions among the general population, considering the background and characteristics of each individual were suggested [30]. The United States also presented online mental health approaches, such as those used in China to examine and treat individuals with anxiety related to a dysfunctional coronavirus [31]. Denmark, on the other hand, expressed concern about increased demand for psychiatric treatment in the context of the pandemic and its consequences [32].

Indeed, illness, long hospitalization, death of a loved one, cessation of work, compulsory quarantine measures lasting several months, lack of reserves, stigmatization, are factors that can be affected, especially those who are more sensitive to stress and who are already suffering from a psychological pathology [47]. Easily accessible short- and long-term mental health care structures could be essential to meet this need [48], and psychologists will always have to keep the torch of the best-known medicine of hope [47].

\section{External and Internal Validity}

This is a systematic review of anxiety, depression, and sleep quality disorders observed during the COVID-19 pandemic. The studies included in this review have certain limitations, for example, most studies are crosssectional and of short duration, however, psychological stress may accumulate over time and have an impact later in the outbreak. The data were based on subjective responses using questionnaires limiting the generalizability of the results. Some causal relationships have not yet been established. For example, anxiety can increase stress, and stress can increase anxiety, anxiety leads to altered sleep, and poor quality sleep increases anxiety. Most studies included in the review are from only one country (China), so the results may not be the same in many developing countries.

\section{Recommendations for Future Research}

The long-term mental health implications of COVID-19 may take weeks or months to fully emerge, so further investigation is needed to determine the severity of this pandemic in other countries, particularly those with less developed mental health facilities. There is also a need to assess the impact of COVID-19 on other populations likely to be affected, such as children, immunodeficient people, and those facing barriers in accessing health care. Follow-up studies to assess the risk factors associated with the psychological impact of COVID-19 infection should be investigated in future long-term studies. Future studies should also include objective indicators of stress, such as measuring serum cortisol levels with the questionnaire.

\section{CONCLUSION}

This systematic review provides valuable information on psychological responses to COVID-19. Our results reveal a significant mental health problem during the COVID-19 epidemic in individuals in China, Iran, Singapore, India, Italy, the USA, and Denmark. Women, youth, people spending too much time on social media, and health care workers were at high risk of psychological problems.

These findings contribute directly to the development of psychological interventions that can minimize the psychological impact, anxiety, depression, stress, and sleep disturbances during the COVID-19 epidemic and provide a reference for control, prevention, and treatment during the remainder of the COVID-19 epidemic, which is still ongoing at the time of writing this manuscript.

\section{LIST OF ABBREVIATIONS USED}

GAD: General Anxiety Disorders; CES-D: Center for Epidemiologic Studies-Depression scale; PSQI: The Pittsburgh Sleep Quality Index; CPDI Score: Peritraumatic Distress Index; DMHWBS 2016: The Danish 
Mental Health and Well-Being Survey 2016; PTSD: Posttraumatic stress disorder.

\section{Conflict of Interest: None to Declare}

Source of funding: No funding

\section{REFERENCES}

1. Ornell F, Schuch JB, Sordi AO, Kessler FHP. "Pandemic fear" and COVID-19: mental health burden and strategies. Brazilian Journal of Psychiatry, 2020.

2. Jiao WY, Wang LN, Liu J, Fang SF, Jiao FY, Pettoello-Mantovani M, Somekh E. Behavioral and Emotional Disorders in Children during the COVID19 Epidemic. The Journal of Pediatrics, 2020.

3. Coughlin SS. Anxiety and Depression: Linkages with Viral Diseases. Public Health Reviews, 2012; 34: 7. doi: $10.1007 /$ BF03391675.

4. Cournos F, Mckinnon K, Sullivan G. Schizophrenia and comorbid human Immunodeficiency Virus or Hepatitis C Virus. The Journal of clinical psychiatry, 2005; 66(Suppl 6): 27-33.

5. Kiecolt-Glaser JK, Glaser R. Depression and immune function: central pathways to morbidity and mortality. Journal of psychosomatic research, 2002; 53: 873-6.

6. Dubois $T$, Reynaert C, Jacques $D$, Lepiece B, Patigny P, Zdanowicz N. Immunity and psychiatric disorders: variabilities of immunity biomarkers are they specific. Psychiatr Danub, 2018; 30: 447-51.

7. Prince M, Patel V, Saxena S, Maj M, Maselko J, Phillips M, Rahman A. No Health Without Mental Health. Lancet, 2007; 370: 859-77. doi: 10.1016/S0140-6736(07)61238-0.

8. Robson D, Gray R. Serious mental illness and physical health problems: a discussion paper. International journal of nursing studies, 2007; 44: 457-66.

9. Fiorillo A, Gorwood P. The consequences of the COVID-19 pandemic on mental health and implications for clinical practice. Eur Psychiatry, 2020; 63: e32-e32. doi: 10.1192/j.eurpsy.2020.35.

10. Williamson V, Murphy D, Greenberg N. COVID-19 and experiences of moral injury in front-line key workers. Occup Med (Lond), 2020: kqaa052. doi: 10.1093/occmed/kqaa052.
11. DePierro J, Lowe S, Katz C. Lessons learned from 9/11: Mental health perspectives on the COVID-19 pandemic. Psychiatry Res 2020a; 288: 113024. doi: 10.1016/j.psychres.2020.113024.

12. Moher D, Liberati A, Tetzlaff J, Altman DG, the PRISMA Group. Preferred Reporting Items for Systematic Reviews and Meta-Analyses: The PRISMA Statement. Annals of Internal Medicine, 2009; 151: 264-9. doi: 10.7326/0003-4819-151-4200908180-00135.

13. Cai H, Tu B, Ma J, Chen L, Fu L, Jiang $Y$, Zhuang Q. Psychological Impact and Coping Strategies of Frontline Medical Staff in Hunan Between January and March 2020 During the Outbreak of Coronavirus Disease 2019 (COVID-19) in Hubei, China. Med Sci Monit, 2020; 26: e924171-e924171. doi: 10.12659/MSM.924171.

14. Gao J, Zheng P, Jia Y, Chen H, Mao Y, Chen S, Wang $Y$, et al. Mental health problems and social media exposure during COVID-19 outbreak. PLoS One, 2020; 15: e0231924-e0231924. doi: 10.1371 / journal. pone. 0231924 .

15. Huang $Y$, Zhao N. Generalized anxiety disorder, depressive symptoms and sleep quality during COVID-19 outbreak in China: a web-based crosssectional survey. Psychiatry Res, 2020; 288: 112954. doi: 10.1016/j.psychres.2020.112954.

16. Li S, Wang Y, Xue J, Zhao N, Zhu T. The Impact of COVID-19 Epidemic Declaration on Psychological Consequences: A Study on Active Weibo Users. Int J Environ Res Public Health, 2020; 17: 2032. doi: 10.3390/ijerph17062032.

17. Meng $H, X u Y$, Dai J, Zhang $Y$, Liu B, Yang $H$. Analyze the psychological impact of COVID-19 among the elderly population in China and make corresponding suggestions. Psychiatry Research 2020; 289: 112983. doi: $10.1016 /$ j.psychres.2020.112983.

18. Qiu J, Shen B, Zhao M, Wang Z, Xie B, Xu Y. A nationwide survey of psychological distress among Chinese people in the COVID-19 epidemic: implications and policy recommendations. Gen Psychiatr, 2020; 33: e100213-e100213. doi: 10.1136/gpsych-2020-100213 
19. Tan W, Hao F, Mclntyre RS, Jiang L, Jiang X, Zhang $L$, et al. Is returning to work during the COVID-19 pandemic stressful? A study on immediate mental health status and psychoneuroimmunity prevention measures of Chinese workforce. Brain, Behavior, and Immunity, 2020. doi: 10.1016/j.bbi.2020.04.055.

20. Wang C, Pan R, Wan X, Tan Y, Xu L, Ho CS, Ho RC. Immediate Psychological Responses and Associated Factors during the Initial Stage of the 2019 Coronavirus Disease (COVID-19) Epidemic among the General Population in China. Int J Environ Res Public Health, 2020; 17: 1729. doi: 10.3390/ijerph17051729.

21. Wang C, Pan R, Wan X, Tan Y, Xu L, Mclntyre RS, et al. A longitudinal study on the mental health of general population during the COVID-19 epidemic in China. Brain Behav Immun, 2020: S08891591(20)30511-0. doi: 10.1016/j.bbi.2020.04.028.

22. Xiao $H$, Zhang $Y$, Kong $D$, Li S, Yang N. Social Capital and Sleep Quality in Individuals Who SelfIsolated for 14 Days During the Coronavirus Disease 2019 (COVID-19) Outbreak in January 2020 in China. Med Sci Monit, 2020a; 26: e923921e923921. doi: 10.12659/MSM.923921.

23. Xiao H, Zhang $Y$, Kong D, Li S, Yang N. The Effects of Social Support on Sleep Quality of Medical Staff Treating Patients with Coronavirus Disease 2019 (COVID-19) in January and February 2020 in China. Med Sci Monit, 2020b; 26: e923549-e923549. doi: 10.12659/MSM.923549.

24. Xie X, Xue Q, Zhou Y, Zhu K, Liu Q, Zhang J, Song R. Mental Health Status Among Children in Home Confinement During the Coronavirus Disease 2019 Outbreak in Hubei Province, China. JAMA Pediatr, 2020: e201619. doi: 10.1001/jamapediatrics.2020.1619.

25. Xu J, Xu Q-H, Wang C-M, Wang J. Psychological status of surgical staff during the COVID-19 outbreak. Psychiatry Res, 2020; 288: 112955112955. doi: 10.1016/j.psychres.2020.112955.
26. Yuan S, Liao Z, Huang $H$, Jiang B, Zhang $X$, Wang $Y$, Zhao M. Comparison of the Indicators of Psychological Stress in the Population of Hubei Province and Non-Endemic Provinces in China During Two Weeks During the Coronavirus Disease 2019 (COVID-19) Outbreak in February 2020. Med Sci Monit, 2020; 26: e923767-e923767. doi: $10.12659 / M S M .923767$.

27. Zhu S, Wu Y, Zhu C-Y, Hong W-C, Yu Z-X, Chen Z$\mathrm{K}$, et al. The immediate mental health impacts of the COVID-19 pandemic among people with or without quarantine managements. Brain Behav Immun, 2020: S0889-1591(20)30601-2. doi: 10.1016/j.bbi.2020.04.045.

28. Chew NWS, Lee GKH, Tan BYQ, Jing M, Goh Y, Ngiam NJH, et al. A multinational, multicentre study on the psychological outcomes and associated physical symptoms amongst healthcare workers during the COVID-19 outbreak. Brain, Behavior, and Immunity, 2020. doi: 10.1016/j.bbi.2020.04.049.

29. Tan B, Chew N, Lee G, Jing M, Goh Y, Yeo L, et al. Psychological Impact of the COVID-19 Pandemic on Health Care Workers in Singapore. Annals of internal medicine, 2020. doi: 10.7326/M20-1083.

30. Moccia L, Janiri D, Pepe M, Dattoli L, Molinaro M, De Martin V, et al. Affective temperament, attachment style, and the psychological impact of the COVID-19 outbreak: an early report on the Italian general population. Brain, Behavior, and Immunity, 2020; 87: 75-9. doi: 10.1016/j.bbi.2020.04.048.

31. Lee SA, Jobe MC, Mathis AA. Mental health characteristics associated with dysfunctional coronavirus anxiety. Psychol Med, 2020: 1-2. doi: 10.1017/S003329172000121X.

32. Sønderskov K, Dinesen P, Santini Z, Østergaard S. The Depressive State of Denmark during the COVID-19 Pandemic. Acta Neuropsychiatrica, 2020. doi: $10.1017 /$ neu.2020.15.

33. Moghanibashi-Mansourieh A. Assessing the anxiety level of Iranian general population during COVID19 outbreak. Asian Journal of Psychiatry, 2020; 51: 102076. doi: 10.1016/j.ajp.2020.102076.

34. Brown GR, Rundell JR, McManis SE, Kendall SN, Zachary R, Temoshok L. Prevalence of psychiatric disorders in the early stages of HIV infection. Psychosomatic Medicine, 1992. 
35. Hughes FA. H1N1 pandemic planning in a mental health residential facility. Journal of psychosocial nursing and mental health services, 2010; 48: 3741.

36. Kamara S, Walder A, Duncan J, Kabbedijk A, Hughes $P$, Muana A. Mental health care during the Ebola virus disease outbreak in Sierra Leone. Bulletin of the World Health Organization, 2017; 95: 842 .

37. Lancee WJ, Maunder RG, Goldbloom DS. Prevalence of psychiatric disorders among Toronto hospital workers one to two years after the SARS outbreak. Psychiatric services, 2008; 59: 91-5.

38. Spoorthy MS. Mental health problems faced by healthcare workers due to the COVID-19 pandemicA review. Asian J Psychiatr, 2020; 51: 102119102119. doi: 10.1016/j.ajp.2020.102119.

39. de Boer J, Lok A, can't Verlaat E, Duivenvoorden HJ, Bakker AB, Smit BJ. Work-related critical incidents in hospital-based health care providers and the risk of post-traumatic stress symptoms, anxiety, and depression: A meta-analysis. Social Science \& Medicine, 2011; 73: 316-26. doi: 10.1016/j.socscimed.2011.05.009.

40. Remes O, Brayne C, van der Linde, R., Lafortune, L. A systematic review of reviews on the prevalence of anxiety disorders in adult populations. Brain Behav, 2016; 6: e00497-e00497. doi: $10.1002 / \mathrm{brb3} .497$.

41. McLean C, Anderson E. Brave men and timid women? A review of the gender differences in fear and anxiety. Clinical Psychology Review. 2009; 29(6): 496-505.
42. Taylor SE, Klein LC, Lewis BP, Gruenewald TL, Gurung RAR, Updegraff JA. Biobehavioral responses to stress in females: Tend-and-befriend, not fight-or-flight. Psychological Review, 2000; 107: 411-29. doi: 10.1037/0033-295X.107.3.411.

43. Brooks SK, Webster RK, Smith LE, Woodland L, Wessely S, Greenberg N, Rubin GJ. The psychological impact of quarantine and how to reduce it: a rapid review of the evidence. The Lancet, 2020.

44. Best P, Manktelow R, Taylor B. Online communication, social media, and adolescent wellbeing: A systematic narrative review. Children and Youth Services Review, 2014; 41: 27-36.

45. Dobrean A, Păsărelu C-R. Impact of Social Media on Social Anxiety: A Systematic. New developments in anxiety disorders, 2016: 129-49. doi: $10.5772 / 65188$.

46. Keles B, McCrae N, Grealish A. A systematic review: the influence of social media on depression, anxiety and psychological distress in adolescents. International Journal of Adolescence and Youth, 2020; 25: 79-93. doi: 10.1080/02673843.2019.1590851.

47. Das N. Psychiatrist in a post-COVID-19 era-Are we prepared? Asian Journal of Psychiatry, 2020; 51: 102082.

48. DePierro J, Lowe S, Katz C. Lessons Learned from 9/11: Mental Health Perspectives on the COVID-19 Pandemic. Psychiatry Research, 2020b: 113024. 